Revista de la red interuniversitaria de estudios sobre las literaturas rioplatenses contemporáneas en Francia

19 | 2018

La rebelión de los hijos: el judaísmo en la literatura latinoamericana contemporánea entre tradición y asimilación

\title{
Los alcances de la palabra "judío"
}

\section{Tamara Kamenszain}

\section{(2) OpenEdition}

\section{Journals}

Edición electrónica

URL: http://journals.openedition.org/lirico/6666

DOI: $10.4000 /$ lirico.6666

ISSN: 2262-8339

Editor

Réseau interuniversitaire d'étude des littératures contemporaines du Río de la Plata

\section{Referencia electrónica}

Tamara Kamenszain, «Los alcances de la palabra "judío" », Cuadernos LIRICO [En línea], 19 | 2018, Puesto en línea el 21 enero 2019, consultado el 30 abril 2019. URL : http://journals.openedition.org/ lirico/6666 ; DOI : 10.4000/lirico.6666

Este documento fue generado automáticamente el 30 abril 2019.

\section{cc)}

Cuadernos LIRICO está distribuido bajo una Licencia Creative Commons Atribución-NoComercial-

SinDerivar 4.0 Internacional. 


\title{
Los alcances de la palabra "judío"
}

\author{
Tamara Kamenszain
}

Después de 50 años -toda una vida- volví a Jerusalem invitada por la Universidad Hebrea para participar, en marzo de 2017, de un coloquio sobre Alejandra Pizarnik. Me aliviaba la idea de encaminarme hacia ese país, al que por diferentes razones durante esos largos años quise y no quise volver, de la mano de una escritora que provisoriamente voy a llamar "asimilada". Este término que hoy, globalización mediante, suena por lo menos anacrónico, me sirve en principio para aludir, en su acepción menos sofisticada, a alguien que la institucionalidad judía autodenominada "colectividad", consideraría outsider. Siguiendo, entonces, a esa outsider que me aseguraba que el coloquio no estaría centrado en una temática jud ía excluyente, podía yo mantenerme firme, frente a cualquier demanda identitaria, en una posición que, también provisoriamente, voy a llamar de "extranjeridad".

Sin embargo, y aunque el coloquio prometía instalarme en la isla pizarnikiana, a la entrada misma de la ciudad, aún antes de llegar a la universidad, una irrupción sorpresiva de viejos fantasmas me dio la bienvenida. Se trataba de un piquete que mantuvo detenido el tránsito durante más de una hora. Pero lo más asombroso es que no respondía a una huelga sindical, a alguna protesta estudiantil ni a nada que se les pareciera. Los piqueteros en este caso no eran otros que un grupo de alrededor de 100 judíos ortodoxos de todas las edades que, desde sus pesados atuendos del siglo XIX en Europa del Este, gesticulaban y saltaban portando carteles. Pedían algo que yo no entendía pero que claramente no parecía dirigido a Dios. Mi primo, que vive en Israel y que había venido a buscarme al aeropuerto, me explicó que se trataba de una reivindicación laboral pero a la inversa: en vez de pedir trabajo, estos insurgentes pedían no trabajar. Es que por una legislación estatal, los religiosos ortodoxos israelíes quedan eximidos de cumplir con el servicio militar que les corresponden a los demás ciudadanos. Para el trámite de exención, tienen que presentar un certificado que demuestre que están estudiando en algún rabinato. Los que no lo presentan no se eximen y hasta pueden ir a prisión. El eje de la protesta giraba, entonces, alrededor del pedido de no tener que presentar el certificado. (Por comentarios que escuché, como el gobierno actual les va agregando a estos grupos nuevas prebendas a cambio de votos, es probable que también les concedan ésta.) Tanto mi primo como otros conductores de la inmensa fila de autos que se formó atrás nuestro, espetaban todo tipo de improperios que no entendí pero que imagino podrían resumirse en el argentinísimo "andá a laburar". En mi caso, entré en un sorprendente estado de euforia. Como la mejor de las turistas, no podía dejar de reírme de la escena que me hacía pensar en un blooper. 
No podía dejar de grabar y fotografiar a esos personajes y, lo que más disfruté, fue el inesperado desenlace cuando llegó el camión policial y descargó a un pelotón de uniformados portando palos. Pero antes de que se concretara algún intento de dispersión, los de negras capotas y alados sombreros salieron disparados como si hubieran visto al diablo. Los conductores de los autos seguían gritando cosas que yo no entendía, pero si sigo imaginando argentinismos, se me ocurre que les hubiera gritado "gallinas", esa expresión que en mi país solemos usar para referirnos a la cobardía masculina, sobre todo en el futbol. Lo cierto es que ahora que lo estoy relatando, creo que la alegría que la escena me provocó tiene que ver con que inmediatamente este material se me presentificó bajo la forma de una posible crónica que, como testigo distanciada, me dieron ganas de escribir.

Cincuenta años antes, la adolescente que había llegado a Jerusalem se encontraba en una situación opuesta a la de esta posible cronista: en vez de querer preservar la condición de extranjera, estaba buscando resolver el problema de su identidad. Y si bien Levinas dice que interrogarse sobre la identidad judía ya es de algún modo haberla perdido, la adolescente se había embarcado en una búsqueda difícil y conflictiva guiada por el supuesto de que tradición y asimilación eran parte de un dualismo irreconciliable (Levinas 1997). Como se puede suponer, ella traía en las valijas una pesada carga de mandatos familiares. Intuyendo que se encontraba al borde de lo que Stephane Moses llama, para esos casos de judaísmo heredado, "la rebelión de los hijos", sus padres la habían enviado a pasar un largo período en Israel, con la secreta esperanza de que allí se soldaría cualquier grieta identitaria. La adolescente, en cambio, esperaba de ese viaje otro tipo de revelación. Y la obtuvo. Volvió a su país con la seguridad de que esa extrañeza que había experimentado en Israel, esa sensación dolorosa de estar exiliada en una lengua y unas costumbres que no le pertenecían, tenía sin embargo que ver con lo que ella iba intuyendo que era otro modo de volverse ya no israelí pero sí judía. Y si es cierto que la escritura brinda, de algún modo, una promesa de extranjeridad -Deleuze nos pide trazar sobre la lengua materna una especie de lengua extranjera- se trataba de pasar al papel todo lo que del judaísmo era escribible para transformarse en lo que Edmond Jabès, pensándose en bloque como judío/escritor, dice de sí mismo: un “extranjero doble" o un "judío de los judíos" (Jabès 2000).

Así es como De este lado del Mediterráneo, mi primer libro, alude desde el título mismo a un tránsito doble que contrabandea de aquí para allá experiencias foráneas. Los Beatles descubiertos sintonizando una radio árabe mientras la adolescente cosechaba naranjas en un kibutz, o el barrio ortodoxo Mea Shearim, -donde seguramente viven muchos de los que estaban en el piquete- relacionado con la Éfeso de Heráclito, son calcomanías de un viaje que, aún habiendo culminado hace 50 años del otro lado del Mediterráneo, se sigue prolongando hoy. La travesía consiste en encontrar en lo judío lo no judío y viceversa. Es por eso tal vez que la palabra "judío" aparece en todos mis libros de un modo casi obsesivo aunque siempre aliándose en forma paradojal con cadenas de sentido que la empujan a circular por afuera del discurso ghéttico. Es como si lanzar esa palabra, que por un lado escandaliza al antisemita pero por otro avergüenza al judío vergonzante, me permitiera, usándola como un diapasón, encontrar un tono. El tono de una hija rebelde que -desde la adolescencia hasta hoy-cada vez que quiere escribir otra cosa escribe "judío" y cada vez que escribe "judío" se le abren líneas de fuga para escribir otra cosa. Quedaría por preguntarse si a eso que siempre nos encuentra aunque huyamos se lo puede llamar tradición. No lo sé, pero lo cierto es que, esquivando dualismos, parada entre la asimilación y la tradición, fue como llegué en marzo de 2017 a Israel, bajo la invocación de "Pizarnik en Jerusalem", ese afortunado título del coloquio que remite, por una vía regia, a Hannah Arendt. Desde sus punzantes anotaciones sobre el juicio a Eichmann, escritas muy cerca del Monte Scopus, la filósofa escandalizó, como hija rebelde, a una colectividad que hasta llegó a considerarla una judía antijudía. 
Alejandra Pizarnik, por su parte, también fue, nos dice Edgardo Dobry, una hija rebelde pero "no sólo por una divergencia con el origen sino por una tardía (y no del todo lograda) vocación de regreso" (Dobry 2017). Es como si la poeta hubiera ido velando y desvelando la condición judía al ritmo de sus investigaciones literarias. En la última etapa de su producción que se consolida con el texto teatral La bucanera de Pernambuco o Hilda la polígrafa y que podría ser definida como una etapa "poligráfica", logra liberarse de la cárcel retórica del lirismo ("me horroriza el lenguaje poético") y se entrega a un desenfrenado reencuentro con lenguas infantiles perdidas. A este juego nuevo que, entre otras adquisiciones, la acerca a viejos significantes judíos, ella lo define como non sense pero también como innocence. En este sentido es que Pizarnik reconoce al judaísmo como un secreto a futuro, anticipado por "la hija de mi voz": "ser judío significa, y esto lo escribo porque me lo dicta la hija de mi voz, ser poseedor de un secreto (cáncer de Freud y ruego de K. de quemar sus obras por temor a divulgar)". Se trataría de un secreto que se develará más al modo de una contraseña que al de un idioma: "silbar Danubio Azul en idisch" nos dice en La bucanera.

Entonces, esta asimilada consciente de los límites secretos que la van desasimilando hasta devolverla a sus orígenes de la mano de la rebeldía, parece encajar perfectamente en la categoría de judíos que Hannah Arendt llama "parias concientes". La filósofa los diferencia de los "asimilacionistas", esos que en el afán triunfalista de ocultar su judaísmo y "fascinados con cada nueva nacionalidad", creen que pueden volverse otros. Al no tener éxito, estos asimilacionistas esconden, bajo la fachada del optimismo, una "tristeza desesperada". Para Arendt existe en la historia judía una tradición relegada de parias: "La tradición de Heine, Rahel Varnhagen, Sholom Aleichem, Bernard Lazare, Franz Kafka o incluso Charles Chaplin. Es la tradición de una minoría de judíos que no han querido convertirse en advenedizos, que prefirieron el estatuto de 'parias conscientes'. Todos exhibieron cualidades judías: el 'corazón judío', la humanidad, el humor, la inteligencia desinteresada, son todas cualidades de parias."

El "paria consciente" de Arendt parece ser alguien que no solo no reniega de su minoridad sino que hace de esa extranjería, de esa vulnerabilidad errante, una cualidad productiva. En ese sentido, no sería desacertado incluirla a ella misma dentro de esa tradición. El oxímoron "banalidad del mal" difícilmente podría haber surgido sin esa "inteligencia desinteresada" con la que Arendt se anima a poner en jaque el dualismo bien-mal, ni más ni menos que ante una cuestión tan sensible como el nazismo. En el caso de Pizarnik, se podría decir que en la última etapa de su obra la escritora se anima, a través de otro oxímoron -"escriborrotear"- a trabajar con ese humor que ella misma, preocupada por cómo iba a ser juzgada por sus lectores acostumbrados al lirismo, define como "humor corrosivo" del que "nadie se ríe salvo yo".

Humor, inteligencia desinteresada, corazón judío son cualidades con las que, por suerte, también me fui topando en este segundo viaje. Es que, en un proceso inversamente mellizo al de Lina Meruane en Volverse Palestina, yo ya sabía que no buscaría volverme israelí sino que, en posición de cronista -una especie de extranjera consciente-, tendría la posibilidad de toparme en Israel con lo inesperado. Por ejemplo, el narrador contemporáneo israelí Etgar Keret, cuya obra tuve el placer de descubrir, me mandó de cabeza de nuevo hacia la diáspora. Él lo explica así: "Yo me siento parte de la gran tradición de los judíos de la diáspora. Me siento mucho más afín a Philip Roth o Bashevis Singer o Kafka que a los escritores israelíes, que pueden ser geniales, pero es otra tradición. La diáspora está fundada en el humor y en un tipo de reflexividad que siempre se está preguntando por el sentido de la existencia. En cambio la narrativa israelí tiende más a lo épico y a contar la historia de un grupo. Israel en muchos sentidos es completamente opuesto a la tradición de la diáspora." (Keret 2017)

Inspirado en las brevísimas crónicas minimalistas que escribe Keret, el arquitecto polaco Jakub SzczĘsny construyó en Varsovia -ciudad en la que la mayor parte de la 
familia del escritor fue asesinada durante la invasión nazi- la casa más pequeña del mundo. En un hueco entre dos edificios de $1,20 \times 72 \mathrm{~cm}$ de ancho, se yergue ese utópico habitat en el que Keret se aloja cada tanto. Es el refugio perfecto para que el paria consciente se instale a escribir sin ínfulas épicas ni grandilocuencias (véase al respecto el minirelato "La casa estrecha"). Sería impensable que de un lugar tan reducido pudiera salir una obra que no fuera menor. Arendt diría que ahí solo hay lugar para un "corazón judío".

El artista visual Yair Garbuz es otro paria consciente con el que me topé en este viaje. De Garbuz se podría decir que es un paria doble: por elección pero también por discriminación social. En 2015, días antes de las elecciones presidenciales y representando a la coalición de izquierda, el artista dio un discurso en la Plaza Rabin que escandalizó a ese medio país que terminó llevando al poder a la derecha gobernante. Aludió a los fundamentalistas religiosos como "chupadores de mezuza" (ese talismán que se coloca en el marco de la puerta y que reemplazaría al cirio en nuestra expresión criolla "chupacirio") Dos años después el Ministro de Educación refrendó la condición de paria de Garbuz impidiendo, con triquiñuelas legales, que se le concediera el Premio Nacional por el que un jurado en mayoría había votado. "Soy pintores", la retrospectiva del artista que visité en el Museo de Arte de Tel Aviv, me puso en contacto con ese "nadie" que pinta y escribe -todos los cuadros incluyen escritura- interviniendo cuadros de otros (Picasso, Hooper, Rothko, Franz Kline, etc). "Copiar es la más bella de todas las artes", dice quien también se imagina a sí mismo interviniendo libros ajenos. "Esto lo relaciono con Borges" se puede leer dentro de uno de los cuadros en el que una serie de tapas numeradas como tomos de una enciclopedia imaginaria hacen pensar en una operación borgeana. Los pintores o escritores que soy, parece decir Garbuz me premian regalándome su identidad para que los copie al mismo tiempo que me libero de la mía.

No sé cómo se las arregla con sus problemas de identidad el profesor argentino con el que me topé en el Coloquio y que hace más de veinte años vive en Jerusalem. Lo que sí sé es que además de enseñar entre otros autores a Néstor Perlongher en la Universidad Hebrea, coordina grupos de estudio donde algunos argentinos -nuestro mismísimo embajador incluido- lo van a escuchar hablar sobre Cortázar o Arlt. Además de estas actividades, el singular profesor cruza una vez al mes la frontera, no sin correr riesgos, para encontrarse con un grupo de colegas palestinos. El objetivo es pensar juntos posibles soluciones para un conflicto que, a partir del asesinato de Rabin, se sigue agravando cada día más.

¿Qué es entonces ser judío hoy en Israel? ¿Insistir, como los integrantes del piquete, con reivindicaciones elitistas en nombre de un judaísmo que se cree el verdadero? ¿Huir cada tanto a la diáspora, como Keret, para encontrarle un tono a sus escritos? ¿"Asimilarse" a producciones artísticas de otros, como Garbuz? ¿Enseñar literatura argentina en Israel mientras se cruza peligrosamente la frontera en pos de una utopía, como el profesor?

Con estas y otras preguntas en la valija volví a mi país. Tengo la esperanza de haber agotado en este escrito el uso y abuso de la palabra "judío" para que por un buen tiempo no vuelva a aparecer en otros. Sin embargo, como buena judía que soy -iya volví a usar la palabrita!- inmediatamente me aparece otra pregunta: ¿y ahora de qué me disfrazo? 


\section{BIBLIOGRAFÍA}

Arendt Hannah, Una revisión de la de la historia judía y otros ensayos, Buenos Aires, Paidós, 2006.

Deleuze Gilles, Crítica y clínica; Barcelona, Anagrama, 1997.

Dobry Edgardo, “Pizarnik y Gelman ante la ley inaccesible”, Cuadernos LIRICO [en línea], no 17, 2017.

Jabès Edmond, Del desierto al libro. Entrevista con Marcel Cohen, Madrid, Trotta, 2000.

Keret Etgar. Los siete años de abundancia; Ciudad de México: Sexto Piso, 2017.

-- "No puedo ser gracioso si todo está bien". Entrevista de Mauro Libertella, Santiago de Chile, Universidad Diego Portales, Revista Dossier, nº 35, 2017.

Levinas Emmanuel, Difficult Freedom, Baltimore, Johns Hopkins University Press, 1997.

Meruane Lina, Volverse Palestina, Santiago de Chile, Penguin Random House, 2014.

Moses Stéphane, El ángel de la historia: Rosenzweig, Benjamin, Scholem, Madrid, Cátedra, 1997.

Pizarnik Alejandra, Diarios, Barcelona, Lumen, 2003.

-- Prosa Completa, Barcelona, Lumen, 2002. 